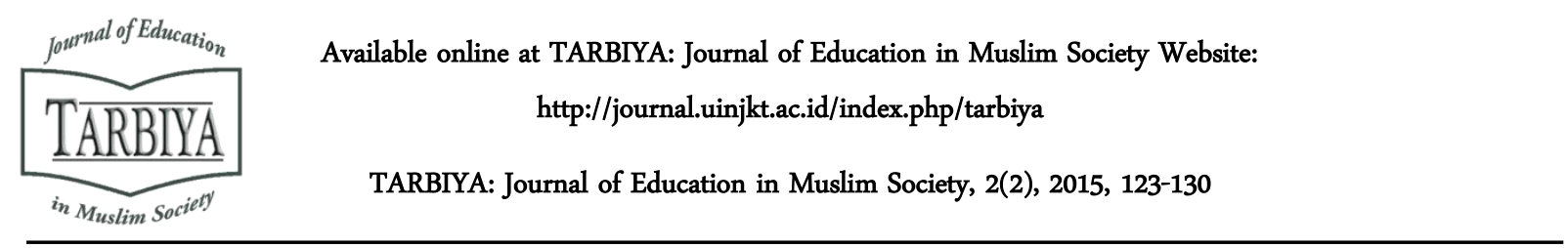

\title{
CONSTRUCTIVISM BASED LEARNING: DESIGN AND PRACTICE
}

\author{
Lia Kurniawati, Abdul Muin, Ramdani Miftah \\ Syarif Hidayatullah State Islamic University of Jakarta, Indonesia \\ E-mail: lia.kurniawati@uinjkt.ac.id; abdul.muin@uinjkt.ac.id; ramdani.miftah@uinjkt.ac.id
}

Received: $20^{\text {th }}$ August 2015; Revised: $08^{\text {th }}$ October 2015; Accepted: $04^{\text {th }}$ December 2015

\section{Abstract}

One of many problems in the madrasahs is that learning processes less-involve students actively (teachercentered), thus, it affects to the improvement of learning outcomes and quality of the graduates. The purposes of this study are, firstly, to analyze what type of constructivism learning models, which can be developed to overcome madrasahs' problems. Secondly, how to design and implement a learning plan based on the developed constructivism models. This research was conducted at Private Islamic Elementary School (Madrasah) Ad-Diyanah Ciputat, South Tangerang. Research method used in this study is descriptive-qualitative research. The results showed that the active learning models based on constructivism are suitable to be developed in the Madarasah, which were the models of Problem Based Learning (PBM), Realistic Learning, Inquiry Learning and Thematic Learning and also how the development of the learning processes from the lesson plans to the learning implementation showed a paradigm shifting from teacher-centered to student-centered.

Keywords: learning constructivism; realistic mathematics learning; problem-based learning; inquiry learning, thematic learning

\begin{abstract}
Abstrak
Salah satu permasalahan di madrasah-madrasah adalah proses pembelajaran yang kurang melibatkan siswa secara aktif (berpusat pada guru), sehingga hal ini mengakibatkan pada peningkatan hasil belajar dan kualitas lulusan. Tujuan dari penelitian ini adalah, pertama, untuk menganalisis jenis model pembelajaran konstruktivisme apa yang dapat dikembangkan untuk mengatasi permasalahan di madrasah. Ke dua, bagaimana merancang dan melaksanakan rencana pembelajaran berdasarkan model konstruktivisme yang dikembangkan. Penelitian ini dilaksanakan di Sekolah Dasar Swasta (madrasah) Ad-Diayanah Ciputat, Tangerang Selatan. Metode penelitian yang digunakan adalah metode deskriptif-kualitatif. Hasil penelitian menunjukkan bahwa model pembelajaran aktif yang berbasis konstruktivisme sesuai untuk dikembangkan di madrasah, yakni model pembelajaran Problem Based Learning (PBL), Pembelajaran Realistis, Pembelajaran Inkuiri dan Pembelajaran Tematik, juga bagaimana pengembangan proses pembelajaran dari rencana pembelajaran ke pelaksanaan pembelajaran menunjukkan perubahan paradigma dari berpusat-pada-guru menjadi berpusat-pada-siswa.
\end{abstract}

Kata kunci: Konstruktivisme pembelajaran; pembelajaran matematika realistis; pebelajaran berbasismasalah; pembelajaran inkuiri, pembelajaran tematik

How to Cite : Kurniawati, L., Muin, A., and Miftah, R. (2015). Constructivism Based Learning: Design and Practice. TARBIYA: Journal Of Education In Muslim Society, 2(2), 123-130. doi:10.15408/tjems.v2i2. 3183.

Permalink/DOI: http://dx.doi.org/10.15408/tjems.v2i2.3183 


\section{Introduction}

Madrasah quality is inseparable from the quality of students, teachers, curricula, management, and graduates. The five components are the dimension in improving the madrasahs' quality. The students, teachers, and curricula are the component inputs to be organized. On-line process is also an important step to be managed since here the treatment, assessment, and review processes are. The feedback emerging during the evaluation process will be used to prepare upgrade-treatment in order to achieve the expected quality improvement. Graduates are the forefront who used to be indicators to understand the global quality of madrasahs. Therefore, graduate candidates should be prepared, the learning implementation should be supervised, and the results are evaluated.

Among the five elements affecting the quality madrasah, teacher professionalism is a decisive factor in improving the madrasahs' quality. As teachers are the primary resource to manage the learning quality which influences the improvement of graduates' quality. Certain main issues challenge the teachers of how to effectively manage learning, and aplly fun learning for students. Problems found in the field are the variety of students' ability even most of them having lower abilities, the outnumbered students in the large classes, for example 40 number of people in one large class. Teachers' skills in the learning methods, strategies, and media are still insufficient. The result is not only less effective learning quality, but also below standard graduates.

Accordingly, the empowerment focus was likely to direct more on improving the teachers quality in order to boost the quality of students' learning in the classrooms. The quality are improved through the development and practice of active learning using some models of active learning which are quite interesting and fun. This program was expected to enhance teachers' knowledge, understanding, and teachers' best practices in teaching students, so it implicates to the enhancement of the students quality and the graduates.

The problems analyzed and evolved in this study were focused more on teachers' empowerment in developing learning processes in the classrooms. Based on preliminary studies conducted, the main arising problem was related to improve a didactic process. The crucial formula of the problems in this study is a modelbased learning model constructivism anything suitable to be developed in the learning process at the school and how to develop the learning design.

The purposes of this study are:

1. Analyzing what type of constructivism learning models which are able develop and to overcome the problems in the madrasah partners.

2. Designing the lesson plans according to the constructivism developed models.

3. Implementing the lesson plans in accordance with the developed designs.

According to Werrington and Kamii (Vygotsky,1978), who states that "in the constructivist classroom a teacher does not teach children how to solve problems, but to present a problem and encourage students to find their own way to solve the problems ".

The Constructivism models to be studied are:

\section{Problem Based Learning (PBL)}

Boud \& Felleti (1997) assert that PBM is a learning approach which situates the learners (students) with practical problems in the illstructured form, open-ended stimulation in learning. Duch, Groh, \& Allen (2001), states 
that the PBM is a learning approach that involves the formulation of the interrelated problems with learning objectives and assessment are interrelated.

Ibrahim (2000) adds more that the problem-based learning approach consists of five main stages, namely:

Stage 1: students' orientation towards the issue.

Phase 2: organizing students to learn.

Stage 3: guiding the individual investigations.

Stage 4: developing and presenting the works.

Stage 5: analizing and evaluating the problemsolving process.

\section{Realistic Mathematics Education / Realistic Mathematics Education}

According to Treffers (1991), who explicitly found the idea, there are two types of mathematical in the context of education, the horizontal and vertical mathematization.

According to Gravemeijer (1994), the learning characteristics of realistic mathematics can be translated into the following five activities: 1) Phenomenological Exploration; 2) Bridging by Vertical Instrument; 3) Student Contribution; 4) Interactivity; 5) Intertwinning

\section{Learning Inquiry}

Inquiry model defined by Piaget (Sund and Trowbridge, 1973) as: Learning to prepare the situation for children to do his own experiment; in a broader sense, to see what happens, what they wants to do something, to use the symbols and to look for answers to the question itself, to link the fidings each other, to compare what was found to the others'findings.

According to Bruce (1992) Learning steps based on inquiry learning are as follows: 1) Formulating the problem; 2) Supervising or observation; 3) Analyzing and presenting the results in writings, pictures, reports, charts, tables, and other works; 4) Communicating or presenting the works to the readers, classmates, teachers, or other audience

\section{Thematic Learning}

Thematic learning is defined as an integrated learning which uses the theme to link several subjects to provide meaningful learning experiences for learners.

Characteristics of thematic learning : 1) Student-centered; 2)Providing direct experiences ;2) No subjects' classification; 3)Presenting an integrated concept on various subjects; 4) Be flexible; 5) The learning process is adjustable with the students' interests and needs; 6) Applying the principles of active, creative, effective, and fun learning.

The theme examples of thematic learning design was "Indahnya Kebersamaaan" (The Beauty of Togetherness/union)

1. Look at the the images of traditional houses below!

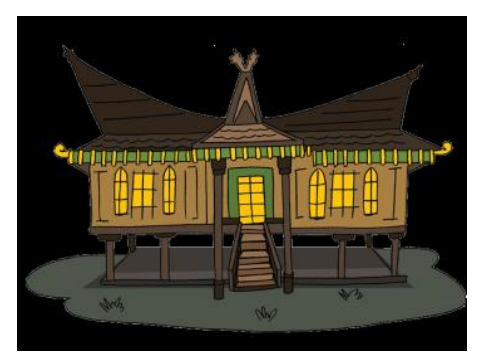

- 'Lontik' Traditional House

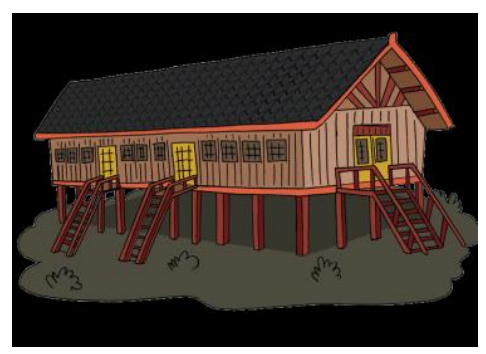

- 'Panjang' Traditional House 


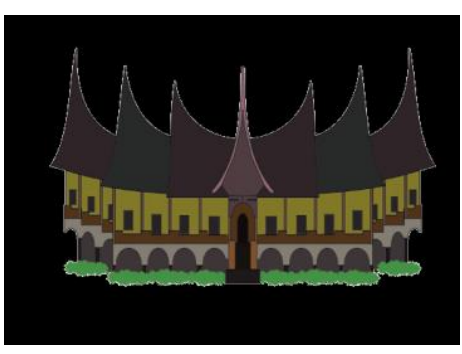

- 'Minang / Gadang' Traditional House a. Mention the characteristics of each of the houses .......

b. Name the parts of the house .....

2. Draw a traditional house that you choose below!

3. Draw parts of the house image that you draw! a. Door

b. Window

c. Roof

d. Staircase

4. Write the name Flat parts of the house!

a. Doors: Build flat amount corner there

b. Window: Build flat, the number of angles there

c. House roof: Build ............. flat, the number of angles there

d. Stairs: Build ................... flat, the number of angles there

5. Let us give the name and the measure of each angle in the picture doors, windows, and roof of the house!

a. Doors: angle $\mathrm{A}=\ldots$, angle $\mathrm{B}=\ldots$, angle $\mathrm{C}=$ $\ldots$, angle $\mathrm{D}=\ldots$, corner ......

b. Window: A corner angle $=$ angle $\mathrm{B}=\mathrm{C}=\mathrm{D}=$ angle corner ......

c. Roofs: $\mathrm{A}=\ldots$ angle, angle $\mathrm{B}=\ldots$, angle $\mathrm{C}=\ldots$, angle $\mathrm{D}=\ldots$, corner $\ldots . .$. d. Stairs: $\mathrm{A}=\ldots$ angle, angle $\mathrm{B}=\ldots$, angle $\mathrm{C}=\ldots$, angle $\mathrm{D}=\ldots$, corner ......

6. Group these angles according to the amount of degrees angle

No Large Angle Picture Angle symbol Roof Window Door Household Name Angle

1. $90^{\circ}$

2. Less than $90^{\circ}$

3. More than $90^{\circ}$

4.

7. Display the results of your work number 1-6 or 1 and 2 sheet on the board based on the lots of the group!

8. Each group must look for the differences and similarities of traditional houses that you and other groups discuss!

a.The similarities are

b. The differences are

c. Beside shape ssimilarity, what other similarities in each regions?

d. Why does each regions have certain things in common?

e. How to take advantage of that similarities?

f. Other than the different forms of the indigenous houses, what is other differences in each region?

g. How to appreciate the differences?

h. Now ask your group friends

You: Assalamu'alaikum

Your friend: Waalaikumussalam

You: What is your name?

Your friend:

You: Where are you from?

Your friend: 
You: What is the name your traditional house?

Your friend:

You: I come from .............. my traditional house is... there are many blunt, tapert parts in the house, taper, and elbows. What about the traditional house?

Your friend:

You: There are many dwellers in my region as farmers, traders, drivers, factory workers and fishermen. How do people work your region?

Your friend:

You: If my dad and my mother work as a seller and teacher at MI Ad Diyanah. They are hard-workers.

Your friend: What about your mother and father?

You: My parents maybe tenacious because they are from ................. Some say that people from.....are diligent and tenacious ................. , If our parents are actively workers, Do we agree or not to study hard?

Your friend:

You: The traditional house of our region, the works of its inhabitants, and the works of our parents have a lot of similarities and differences. As part of our house there is a sharp angled, obtuse, and right-angled though the shape of different parts of the house. Why does God create us with a lot of similarities and differences, huh?

Your friend:

You: Besides the traditional houses, what other jobs which become the more typical of your region?

Your friend:

You: Are you proud of your region?

Your friend:

You: Besides your cultural area, what other cultural region do you know, mention and give examples!

Your friend:

You: How do you appreciate the network of different regions and cultures?

Your friend:

You: We have different regions, traditions, and habits, if we disagree how do we have common opinion?

Your friend:

You: We should be grateful to God because we are blessed with a variety of traditional houses, cultures, religions, ethnics, food and others. If I'm grateful for this by diligently worship, what about you?

Your friend:

\section{Method}

The method, which was used, is qualitativedescriptive. It took place in Ad Diyanah Private Islamic Elementary School (MI), located at Jalan Otto Iskandardinata (Otista) No. 17 A High Sasak Ciputat South Tangerang, Banten.

\section{Results and Discussion}

The common problems which have been revealed was an essential problems: teacher as human resources, students' capabilities, school facilities and infrastructure as well as school management. In fact, it was the frequent problems not only in the madrasahs, but also indeed in almost all madrasahs. However, the more specific problem is still rather difficult to unfold. For example, in one of the researched madrasah, it was found that the teachers had participated in many adequate trainings, they had experienced on more than one time of a variety of research trainings, on a range of research themes/topics, and on a diverse research areas' Unfortunately, it seemed that overall trainings were unable to raise the quality of the madrasahs.

As a whole, there were three subjects areas which had been followed up to be developed in the lesson plan(RPP), implementation, and evaluation to be simulated. The three areas developed a constructivist approach which consists of relistic mathematical model, problembased learning model combined with thematicintegrated format, and learning by inquiry model.

Firstly, in Mathematics. In Mathematics the chosen topic to be implemented was Statisticss 
topic, defined as the collection and presentation of data. To implement constructivism learning approach in maths, it was set to apply Realistics model (Education of Realistics Mathematics). There were several aspects in Mathematics considered to become learning materials for students to be applied. For example, there was student scenario for collecting the existing data in certain schools, by using several methods such as observation, interview, and direct measurement.

Secondly, the subjects of Citizenship Education (Civics), Arts and crafts (SBDP), and Maths. All of three subjects were packed in an integrated thematic learning with problem-based learning model. The main topic of the study was related to a Civics subject theme, "Indahnya Kebersamaan" (The beauty of togetherness/union) ".

Thirdly, the subject of Islamic Culture History (SKI) which was packed in inquiry learning approach. The finding of material aspects to be studied was prototypical characters of Khulafaurosyidin, specificly to the caliph's personalities, Umar bin Khatab. In practice, the students were planned to find the exemplary natures.

The results obtained from this activities were:

1. Learning implementation using mathematical Realistics model in math subject was in the topic Statisticss " Reading and Presenting Data"

2. Learning implementation using inquiry model in the subject of Islamic Culture and History of (SKI), was the topic Khulafa'urrasidin.

3. Learning implementation using thematic and integrated model to Math, SBDP, and Civics subjects was in the "Keberagaman bangsaku (My National Diversity)"theme.
Observation Results of Teaching and Learning Using Problem based Learning Model

Referring to the observation result from the learning using problem-based model, overall implementation of the learning model in the mentored madrassahs was already quite good (64.44\%). This indicated that the mentoring had resulted a shifting in teachers' paradigm from conventional classroom teachings (teachercentered) to active learning (student-centered) ones. Furthermore, there are several points will be explained more about the results.

\section{Observation Results of Teaching and Learning Using Realistics Model}

Observations in learning using Realistics model were conducted by lecturers, as observers and mentors as well. It was conducted to understand the mentoring implementation of learning models for the development of the learning models. The results of the implementation of Realistics model can be seen in the Tabel 4.4:

The results from the observation showed that the implementation was applied quite Realistics learning. The average score of the activities obtained was (73.33\%). It also indicated that based on mentoring result contributed to alter the teachers' perceptions on learning paradigm in the classroom from the conventional one (teacher-centered) to another (student-centered). For better explanation about the results, there are each aspects in Realistics model:

\section{Observation Results of Teaching and Learning Using Inquiry Model}

As observed and implemented in Realistics and Problem based learning, observations on inquiry learning activities were also conducted by the lecturers alongside the mentoring to understand the application and the development 
of inquiry learning model. Observed learning model were inquiry model. The results of the observation on the ongoing inquiry learning activities could be overviewed.

According to the observation guidelines, there were four (4) obvious (researchable) characteristics in the teachers' learning process in the classroom: planning, learning, classroom management and assessment. By and large from the characteristics, the average percentage of obtained results was $78.9 \%$. It means that they taught well based on the current significant improvement of RPP ducument. The RPP's were the revision versions which had led to learning steps using inquiry learning model. Even though the RPP's still showed mistakes, at least it needs meaningless correctionr and reparable to reach the perfect RPP.

Referring to the main issue in the whole research activities, the results showed an improvement in certain aspects, which were:

1. Learning Documents, the Development of the Plan of the Lesson Plans (RPP) was improved after they had participated in the enrichment program by workshops and mentoring. They demonstrated to apply more active learning, which were indicated from their selection of learning indicators which led to the development of high-level thinking skills'

2. Students in The Learning Process. In the learning process students demonstrated active learning in Math subject based on Realistics models. The implementation of the other subjects was clearly observed that there were some students who were passive learners (in terms of learning and thinking activities).

3. Teacher in the learning process. In the process , generally, the teachers demonstrated their mastery of learning methods and concepts or subject substance.
Although it was found one teacher who implemented such a little unflexible learning, or even unabled to distinguish how to teach the conventionally and how to teach the construtivist one.

4. Overall, the finding results could develop better active learning models based on constructivism approach for further improvement. Nonetheless, it is undoubtfully necessary to empower more in advance for achieving the expected goals regarding to the development of learning models.

\section{Conclusion}

Based on the aforementioned data analysis, findings, and discussions in previous chapter, it can be concluded that the models of active learning based on constructivism is suitable to be developed in Islamic Elementary School (Madarasah Ibtidaiyah/MI). For instance: Problem based learning (PBL), Realistics Mathematics Education (RME), Inquiry Learning, and Thematic Learning.

Learning development from RPP to its implementation showed the existance of paradigm shifting from teacher-centered to student-centered.

\section{References}

Boud, D. and Felleti. (1997). The Challenge of Problem-Based Learning. London: Kogapage.

Bruce, W.C. and J.K. Bruce. (1992). Teaching with Inquiry. Maryland: Alpha Publishing Company, Inc.

Duch, B.J., Groh, S. E., and Allen, D.E. (2001). "Why Problem-based learning?". The power of problem-based learning. Virginia: Stylus Publishing. 
Gravemeijer, K. P. E. (1994). Developing Mathematics Education. Utrecth : CD Press/ Freudentasl Institute

Ibrahim, M. and Nur, M. (2000). Pengajaran Berdasarkan Masalah. Surabaya: UNESAUniversity Press.

Sund and Trowbridge. (1973). Teaching Science by Inquiry in the Secondary School. Columbus: Charles E. Merill Publishing Company.
Trefers, A. (1991). Realistics Mathematics Education in The Netherlands 1980- 1990 in Realistics Mathematics Education in Primary School. Utrech: Freudenthal Institute.

Vygotsky, L. S. (1978). Mind in Society. Cambridge, MA: Harvard University Press. 